\title{
PEMBERDAYAAN MASYARAKAT DALAM PEMBUATAN MIKROORGANISME LOKAL (MOL) DAN PEMANFAATANNYA PADA TANAMAN ANGGREK
}

\author{
Diarsi Eka Yani*), Nurul Huda, Idha Farida, Ernik Yuliana \\ Program Studi Agribisnis, FST-Universitas Terbuka \\ Email: diarsi@ecampus.ut.ac.id ${ }^{*}$
}

\begin{abstract}
One of the products that are beneficial to humans is local microorganisms (MOL). MOL is a liquid containing microorganisms produced by themselves from natural materials around us, where these materials serve as a medium for the life and development of microorganisms that are useful in accelerating the destruction of organic materials (decomposers) or as additional nutrients for plants. Activity community service aims to increase knowledge and skills about the manufacture of local microorganisms (MOL) and their use in orchids. Activity community service was carried out at PKK Taman Darmaga Permai Bogor with a membership of about 40 people. Stages of activity community services namely: (1) Location survey/licensing; (2) Theoretical training: (3) Practical training; (4) Spraying; and (5) Monitoring and evaluation. In addition to the stages above, the team community service also distributed questionnaires to assess the level of knowledge, mental attitudes, and skills of participant community service on the manufacture of MOL and its use in orchid plants. Training participant community service general, they can understand about the making of $\mathrm{MOL}$ and the cultivation of orchids in theory. After they understand the theory of making MOL for orchids, they can also practice making MOL in their own homes. Furthermore, the MOL that has been made by PKK participants is applied to orchid plants by spraying all parts of the plant. From the results of monitoring and evaluation from the team community service, the orchid plants that had been sprayed with MOL by the training participants appeared to be thriving and blooming diligently.
\end{abstract}

Keywords: local microorganism, organic material, orchid plant

\begin{abstract}
ABSTRAK
Salah satu produk yang bermanfaat bagi manusia adalah Mikroorganisme Lokal (MOL). MOL adalah cairan yang mengandung mikroorganisme hasil produksi sendiri dari bahan-bahan alami di sekitar kita, dimana bahan-bahan tersebut sebagai media untuk hidup dan berkembangnya mikroorganisme yang berguna dalam mempercepat penghancuran bahan-bahan organik (dekomposer) atau sebagai tambahan nutrisi bagi tanaman. Kegiatan abdimas bertujuan untuk meningkatkan pengetahuan dan keterampilan tentang pembuatan mikroorganisme lokal (MOL) dan pemanfaatannya pada tanaman anggrek. Kegiatan abdimas dilakukan di PKK Taman Darmaga Permai Bogor dengan jumlah anggota sekitar 40 orang. Tahapan kegiatan abdimas yaitu: (1) Survei lokasi/perijinan; (2) Pelatihan secara teori: (3) Pelatihan secara praktik; (4) Penyemprotan; dan (5) Monitoring serta evaluasi. Selain tahapan di atas, tim abdimas juga menyebarkan kuesioner untuk menjaring tingkat pengetahuan, sikap mental, dan keterampilan peserta abdimas terhadap pembuatan $\mathrm{MOL}$ dan pemanfaatannya pada tanaman anggrek. Peserta pelatihan abdimas pada umumnya dapat memahami tentang pembuatan MOL dan budidaya tanaman anggrek yang dilakukan secara teori. Setelah mereka memahami tentang teori pembuatan MOL
\end{abstract}


tanaman anggrek, mereka juga dapat mempraktikkan pembuatan MOL di rumah masing-masing. Selanjutnya MOL yang sudah dibuat oleh peserta PKK diaplikasikan ke tanaman anggrek dengan cara di semprot di seluruh bagian tanaman. Dari hasil monitoring dan evaluasi dari tim abdimas, tanaman anggrek yang telah disemprot dengan MOL oleh para peserta pelatihan nampak tumbuh subur dan rajin berbunga.

Kata kunci: mikroorganisme lokal, bahan organik, tanaman anggrek

\section{PENDAHULUAN}

Di daerah perkotaan atau pinggiran perkotaan sering dijumpai pemandangan sampah atau limbah menumpuk yang merusak keindahan kota, sedangkan dari segi sosial, penumpukkan sampah juga meresahkan masyarakat. Sebagai contoh, pembuangan sampah ke sungai akibat sampah menumpuk, semestinya bisa dihindari karena dapat menimbulkan banjir ataupun pembakaran sampah perlu dicegah karena dapat menimbulkan polusi udara. Adanya banjir dan polusi udara membuat masyarakat saling menyalahkan, saling menuding awal terjadinya banjir dan pembakaran. Hal tersebut tentu saja membuat suasana kehidupan bermasyarakat menjadi tidak sehat, bahkan bisa memicu terjadinya konflik masyarakat.

Limbah rumahtangga meliputi: (1) Limbah dapur; (2) Limbah rumah; dan (3) Limbah halaman rumah. Limbah dapur terdiri dari limbah bahan baku masakan, baik nabati atau hewani atau sisa masakan dan limbah wadah plastik atau wadah non plastik. Selain limbah padat, dapur juga memproduksi limbah cair, seperti sisa lemak, air cucian beras, air cucian daging dan sisa kuah. Limbah dalam rumah hampir semuanya berupa limbah kering. Sebagai contoh adalah kertas, kardus, plastik, tisu, debu, logam, kaca, dan kayu. Limbah halaman rumah umumnya berasal dari hasil panen dan hasil pemangkasan tanaman, baik pemangkasan pohon, tanaman perdu, tanaman bunga, tanaman sayuran, herbal bahkan rumput (Soeleman, S dan Donor Rahayu,2014).

Berdasarkan sifat bahannya, terdapat dua jenis limbah yaitu limbah organik dan limbah anorganik. Limbah organik berasal dari sisa-sisa nabati (tumbuhan) maupun hewani. Oleh karena mudah terurai, limbah organik tidak merusak lingkungan, sedangkan limbah anorganik dapat mencemari lingkungan karena sulit terurai atau bahkan tidak dapat di urai. Pemanfaatan limbah rumahtangga mengusung pendekatan $3 \mathrm{R}$, yaitu Reduce-Reuse-Recycle dengan memanfaatkan limbah dapur, limbah dalam rumah, dan limbah halaman rumah.

IImu kesehatan masyarakat (Public Health), didefinisikan oleh Professor Winslow dari Yale University sebagai ilmu dan Seni dalam mencegah penyakit, memperpanjang hidup, dan meningkatkan kesehatan, melalui "Usaha-usaha Pengorganisasian masyarakat. Usaha-usaha yang dimaksud tersebut (https://faisalhp.wordpress.com/2012/02/02/apa-itu-kesehatan-masyarakat/) antara lain adalah: (1) Perbaikan sanitasi lingkungan; (2) Pemberantasan penyakit-penyakit menular; (3) Pendidikan untuk kebersihan perorangan; (4) Pengorganisasian layanan-layanan medis dan perawatan untuk diagnosis dini dan perawatan; dan (5) Pengembangan rekayasa sosial untuk menjamin setiap orang terpenuhi kebutuhan hidup yang layak dalam memelihara kesehatannya. Adapun upaya-upaya yang termasuk ke dalam ranah garapan seorang ahli kesehatan masyarakat antara lain: (1) Pemberantasan penyakit menular dan tidak menular; (2) Pemberantasan vektor; (3) Perbaikan sanitasi lingkungan; (4) Perbaikan gizi masyarakat; (5) Pendidikan kesehatan masyarakat; (6) Pelayanan kesehatan ibu dan anak; (7) Pengawasan sanitasi tempat umum; (8) Mengelola program dan pelayanan kesehatan; (9) Pengawasan makanan, minuman, dan obat; (10) Membina kesehatan pekerja dan tempat kerja; (11) Mengadvokasi kebijakan berwawasan kesehatan; (12) Mengelola data-data kesehatan; (13) Melakukan survei lansepidemiologi; (14) Mengorganisasikan dan memberdayakan masyarakat agar mau dan mampu melakukan hidup sehat, dan masih banyak lagi kegiatan-kegiatan yang berada di bawah ruang lingkup kesehatan masyarakat. 
Dalam konteks kehidupan bermasyarakat di kelompok PKK Taman Darmaga Permai Bogor, upaya kesehatan masyarakat yang akan dilakukan adalah yang terkait dengan perbaikan sanitasi lingkungan dan pendidikan untuk kebersihan persorangan, yang sekaligus dapat dimanfaatkan untuk pemberantasan penyakit menular.

Upaya-upaya tersebut dapat dilakukan secara bergotong-royong mengingat kehidupan bermasyarakat di PKK Taman Darmaga Permai Bogor memiliki hubungan yang erat satu sama lain. Hubungan timbal balik sangat terlihat dalam bermasyarakat. Misalnya, jika hari ini seseorang be rbuat baik menolong tetangganya yang sedang kesusahan maka pada suatu hari nanti apabila ia menemui kesulitan maka para tetangganya pun tidak akan melupakan kebaikannya dan pasti akan menolong. Karakter kehidupan bermasyarakat lainnya yang terlihat di PKK Taman Darmaga Permai Bogor antara lain adalah: (1) Ikatan persaudaraan yang erat antara satu individu dengan individu lain; (2) Saling menghormati dan menghargai antar individu; (3) Saling tolong-menolong antar individu; dan (4) Bisa menjadi panutan bagi individu lain.

Seperti halnya permasalahan yang terjadi di sekitar perumahan, sampah yang merupakan produk rumahtangga juga menjadi permasalahan yang dihadapi. Untuk itu, agar kesehatan lingkungan tetap terjaga dengan baik, sampah yang dihasilkan tersebut perlu dikelola dengan baik, sehingga diharapkan sanitasi lingkungan dapat terjaga dan masyarakat dapat hidup dengan bersih dan sehat.

Di lain pihak, pada umumnya, warga PKK Taman Darmaga Permai Bogor mempunyai pekarangan sempit. Untuk itu teknik penanaman dalam pot merupakan salah bentuk teknik penanaman yang dipandang cocok untuk daerah tersebut. Salah satu tanaman yang ditanam dalam pekarangan yang sempit atau dalam pot adalah tanaman anggrek. Tanaman anggrek banyak dimanfaatkan sebagai komponen utama untuk menghijaukan rumah, yaitu dengan cara ditanam dalam pot maupun digantung. Selain sebagai penghias rumah, fungsi tanaman anggrek sebagai penghasil oksigen menjadikan udara lebih segar. Budidaya tanaman anggrek juga dapat dilakukan pada waktu yang senggang dan dapat dilakukan oleh ibu rumahtangga anggota PKK Taman Darmaga Permai Bogor, baik sebagai peluang untuk mendatangkan keuntungan maupun sebagai penghias rumah.

Anggrek merupakan salah satu jenis tanaman anggrek berbunga yang dapat dipilih untuk ditanam di teras rumah, karena mempunyai nilai artistik yang tinggi dan dapat memberi gambaran karakter si pemilik rumah. Tidak ada yang menyangkal keindahan bunga anggrek. Jumlah kuntumnya yang bervariasi dari satu hingga ratusan kuntum. Bunga-bunga tersebut juga ditemukan dalam berbagai ukuran. Demikian juga keragaman warnanya, semua jenis warna terlihat pada bunga yang dijadikan simbol cinta dan kecantikan ini. Semua keindahan bunga anggrek dapat dinikmati di teras rumah, karena dengan teknik budidaya dan pembungaan yang tepat, kita dapat membuat anggrek yang ditanam di teras rumah rajin berbunga (Syafrezani, 2009).

Beberapa kegiatan yang dapat dilakukan dalam budidaya anggrek adalah: (1) Pemilihan bibit; (2) Pot, media tanam dan rak tanam; (3) Penyiraman; (4) Kelembaban udara, sirkulasi udara, dan cahaya matahari; (5) Pemupukan; dan (6) Pemberantasan hama dan penyakit (Sandra, 2006).

Pada waktu pemilihan bibit, sebaiknya bibit anggrek yang dipilih adalah tanaman yang sudah remaja. Pilih juga beberapa jenis anggrek yang rajin berbunga dan mudah perawatannya, misalnya jenis Cattleya, dan Dendrobium, sedangkan yang ingin memilih jenis anggrek Phalaenopsis (anggrek bulan), maka pilih tanaman yang 2-3 bulan lagi memunculkan tunas bunga. Jenis yang dipilih antara lain Phalaenopsis amabilis dan tipe berbunga besar (Anonim, 2005).

Dalam budidaya anggrek, sebaiknya sebaiknya digunakan pot berbahan gerabah, karena dapat menyerap air sehingga kelembaban di sekitar perakaran terjaga. Di samping itu pot yang digunakan harus berdinding bersih, dan tidak ditumbuhi lumut juga yang memiliki arang kayu yang masih sedikit, atau media yang sama sekali tak ditumbuhi lumut. Hal ini menandakan bahwa media itu baru diganti. Tanaman anggrek remaja yang sudah dipilih, ditempatkan pada rak-rak bersusun, dan diatur berdasarkan selera, tempat yang tersedia, dan pengaturan taman secara keseluruhan. Jenis anggrek yang membutuhkan cahaya matahari banyak, misalnya Cattleya dan Dendrobium ditempatkan pada 
bagian atas, sedangkan bagian yang lebih terlindung oleh matahari bisa ditempati oleh jenis Phalaenopsis (Sandra, 2006).

Penyiraman yang dilakukan pada tanaman anggrek dilakukan 1-2 kali penyiraman pagi (pukul 09.00) dan sore hari (pukul 15.00), tergantung pada kondisi cuaca, bila kondisi hujan bisa dikurangi atau penyiraman ditiadakan. Cahaya matahari sangat berpengaruh terhadap pembungaan anggrek. Penanaman anggrek di teras rumah, harus mempertimbangkan faktor cahaya matahari ini, misalnya anggrek ditanam pada tempat yang terkena matahari pada pagi hari (misalnya sampai dengan pukul 9 atau 10 pagi). Apabila kita tidak dapat mendapatkan tempat di teras yang terkena matahari pagi, kita juga dapat menempatkannya di areal yang terkena matahari langsung tapi dengan memberi naungan dengan kerapatan $55 \%$.

Untuk membungakan Cattleya, Dendrobium, dan Phalaenopsis pemilihan jenis pupuk sangat penting. Sebaiknya dipilih pupuk dengan kadar fosfor dan kalium tinggi. Pupuk majemuk yang digunakan untuk pembungaan minimal memakai 2 merek berlainan, agar kandungan unsur mikro tersedia selengkap mungkin. Pupuk dipakai secara bergantian, misalnya Growmore dan Bioplasma. Frekuensi penyemprotan adalah 2 kali seminggu, dan dosis menurut keterangan pada label kemasan pupuk (Anonim, 2002).

Hama yang sering menyerang anggrek yang ditanam di teras adalah semut, keong kecil, kutu, dan belalang. Jika hama yang menyerang sedikit, sebaiknya membasmi bagian tanaman yang terserang dari hama secara manual. Bila serangan hama sudah terlanjur banyak, bisa dilakukan penyemprotan dengan pestisida, misalnya Dentis, Ephen 588 PP. Tanaman anggrek dapat diserang penyakit, karena bakteri, jamur, dan virus. Gejala penyakit yang ditimbulkan oleh penyebab penyakit tersebut berbedabeda. Bila menemui gejala penyakit pada tanaman anggrek, langsung dilakukan penanggulangan secara manual. Tanaman atau bagian tanaman dipisahkan, dibuang, dan bila perlu dibakar. Jika serangan penyakit sudah mulai banyak, perlu dilakukan pengendalian secara kimiawi, menggunakan Rovral dan Mancozeb (Sandra, 2006).

Salah satu prinsip pertanian organik adalah mendaurulang sisa-sisa pertanian yang ada untuk dijadikan sumber pupuk maupun sebagai pestisida nabati. Pupuk yang digunakan dalam pertanian organik berasal dari hijauan seperti jerami, batang pisang dan dedaunan lainnya di tambah kotoran ternak, yang difermentasi menggunakan MOL. MOL adalah cairan yang mengandung mikroorganisme hasil produksi sendiri dari bahan-bahan alami di sekeliling kita (lokal), dimana bahan-bahan tersebut sebagai media untuk hidup dan berkembangnya mikroorganisme yang berguna dalam mempercepat penghancuran bahan-bahan organik (decomposer) atau sebagai tambahan nutrisi bagi tanaman (Sholah, 2010). MOL merupakan mikroorganisme hasil fermentasi dari bahan yang ada di lingkungan sekitar dan mudah didapat. Penggunaan bahan bakunya disesuaikan dengan potensi di suatu wilayah. Selain sebagai starter atau dekomposer, MOL juga dapat digunakan sebagai pupuk hayati, pestisida organik, dan fungisida dengan dosis yang sangat kecil (Mulyono, 2014).

Mulyono (2014) menyatakan, jenis bahan pembuat MOL terdapat 3 (tiga) komponen utama yang membuat bakteri tumbuh dan hidup subur. Komponen tersebut adalah: (1) Karbohidrat; (2) Glukosa; dan (3) Sumber mikroorganisme. Karbohidrat dapat diperoleh dari air tajin (air cucian beras), sisa gandum, kentang, jagung, singkong dan nasi yang telah basi. Glukosa dapat diperoleh pada bahan yang mengandung gula seperti molase (ampas tebu), gula merah, gula pasir cair, air kelapa, dan seluruh bahan yang mengandung gula. Sumber mikroorganisme dapat diperoleh pada sisa-sisa buah atau sayuran yang busuk, terasi, sisa ikan, rebung bambu, berenuk, bonggol pisang dan ramin (cairan isi perut hewan).

Kelompok PKK Taman Darmaga Permai terbentuk pada tahun 1998. Pembentukannya bertujuan untuk menjalin silaturahim sesama warga Kompleks Taman Darmaga Permai. Kelompok PKK ini memiliki kegiatan sosial diantaranya kegiatan arisan perbulan, pengajian rutin perminggu, dan posyandu. Kegiatan kunjungan ke industri pembuatan nata de coco juga pernah dilakukan. Berbagai kegiatan penyuluhan pernah diperoleh anggota PKK ini, diantaranya tentang manfaat MOL. Namun, pembuatannya belum pernah dipraktekkan. Sampah rumah tangga di dalam komplek ini belum 
termanfaatkan secara optimal. Pembuangan sampah dilakukan tanpa ada penyortiran antara sampah organik dan anorganik. Di lain pihak, anggota kelompok PKK ini memiliki hobi pada tanaman anggrek. Namun belum memiliki pengetahuan yang baik mengenai budidaya tanaman anggrek.

\section{KERANGKA BERPIKIR INTERVENSI}

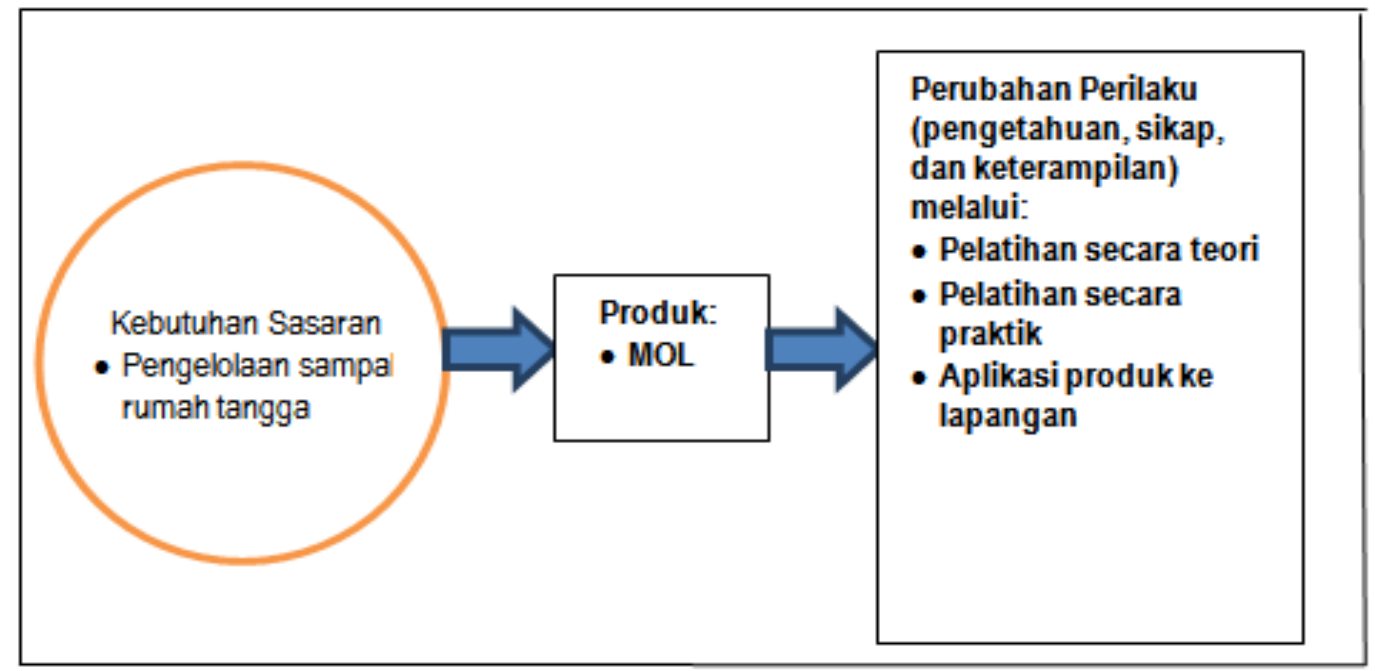

Gambar 1. Kerangka berpikir Abdimas "Pemberdayaan Masyarakat dalam Pembuatan Mikroorganisme Lokal (MOL) dan Pemanfaatannya pada Tanaman anggrek"

Berdasarkan kondisi tersebut di atas, maka tujuan dari artikel ini adalah membahas tentang strategi dan metode pembuatan MOL yang diaplikasikan pemanfaatannya pada tanaman anggrek dalam pot. Secara khusus, tujuan artikel ini adalah membahas tentang hasil implementasi kegiatan abdimas dalam meningkatkan pengetahuan dan keterampilan tentang pembuatan mikroorganisme lokal (MOL) dan pemanfaatannya pada tanaman anggrek.

\section{STRATEGI DAN SOLUSI YANG DITAWARKAN}

Dalam upaya penanggulangan sampah yang ada di lingkungan masyarakat ini, pembuatan MOL, dapat diimplementasikan di perumahan sekitar. Hal ini karena proses pelaksanaannya yang mudah, murah dan sederhana. Untuk itu, sebagai bentuk Tri dharma perguruan tinggi, khususnya dalam hal pengabdian kepada masyarakat, pembuatan MOL tersebut akan dilaksanakan di PKK Taman Darmaga Permai Bogor, Kabupaten Bogor. Tempat tersebut dipilih sebagai lokasi pembuatan MOL, didasarkan pada pertimbangan, kelompok tersebut beranggotakan ibu-ibu rumahtangga yang aktif dalam kegiatan PKK, sehingga mempunyai kelompok, dan ibu-ibu tersebut mempunyai pekarangan yang tidak begitu luas, namun bisa dimanfaatkan untuk budidaya tanaman. Selanjutnya, setelah dilakukan pelatihan pembuatan MOL, ibu-ibu PKK Taman Darmaga Permai Bogor, akan mengaplikasikan hasil pembuatan MOL tersebut untuk disemprotkan ke tanaman anggrek dalam pot.

Pada kegiatan abdimas di lokasi ini dipilih tanaman anggrek. Tanaman anggrek ini dipilih dalam kegiatan abdimas ini, karena besarnya kebutuhan pasar terhadap tanaman anggrek dalam pot dapat dilihat sebagai suatu peluang usaha yang cukup menjanjikan, namun apabila tujuannya bukan untuk peluang usaha, tanaman anggrek dalam pot bisa membuat rumah menjadi lebih asri, di samping juga mudah dalam perawatannya. Menurut Endah (2008), berdasarkan bagian yang dinikmati, tanaman anggrek terbagi menjadi 2 yaitu: (1) Tanaman anggrek daun; dan (2) Tanaman anggrek bunga. Tanaman anggrek daun adalah tanaman anggrek yang memiliki warna warni daun yang indah dengan bentuk daun 
atau tajuk bervariasi, unik dan eksotik. Contoh tanaman anggrek daun adalah Adam Eva (Rhoe discolor), sambang darah, liliparis, sri rejeki, balanceng, palem, Philodendron, keladihias, walisongo, kupinggajah. Adapun tanaman anggrek bunga adalah tanaman yang memiliki kemampuan menghasilkan bunga dengan aneka bentuk, warna, ukuran dan keharuman. Contohnya adalah petunia semusim, geranium, nonamakansirih, anggrek, mawar dan sebagainya.

Adapun pembuatan MOL oleh anggota kelompok PKK di lokasi ini diberikan melalui beberapa tahapan yaitu dengan pelatihan secara teori, pelatihan secara praktik, dan aplikasi produk kelapangan. Diharapkan dengan adanya beberapa tahapan ini anggota kelompok PKK mampu untuk menerapkan secara teori dan praktik pembuatan MOL serta aplikasinya pada tanaman anggrek khususnya tanaman anggrek.

Jadi dapat dikatakan berdasarkan kondisi kehidupan bermasyarakat yang ada di PKK Darmaga Permai Bogor diharapkan pembuatan dan pemanfaatan MOL ini dapat dilaksanakan secara bersamasama dan demi untuk keuntungan dan kepentingan bersama.

\section{STRATEGI PENDEKATAN}

a. Perubahan sikap-perilaku atau kemampuan life-skills komunitas marjinal/wilayah (non tangible) yang diukur dari penguasaan/peningkatan keterampilan praktis dan atau teoretis.

Berdasarkan prinsip-prinsip kebutuhan prioritas masyarakat mitra, maka target luaran yang diharapkan dapat dicapai adalah adanya perubahan perilaku dari Masyarakat PKK Taman Darmaga Permai Bogor dalam pembuatan mikroorganisme lokal (MOL) untuk budidaya tanaman anggrek. Secara khusus, target luaran yang disebagai berikut:

1. Meningkatkan pengetahuan masyarakat di PKK Taman Darmaga Permai Bogor tentang pembuatan mikroorganisme lokal (MOL) dan pemanfaatannya pada tanaman anggrek.

2. Meningkatkan keterampilan masyarakat di PKK Taman Darmaga Permai Bogor tentang pembuatan mikroorganisme lokal (MOL) dan pemanfaatannya pada tanaman anggrek.

3. Meningkatkan keberdayaan masyarakat dalam pembuatan MOL.

4. Meningkatkan keberdayaan masyarakat dalam melakukan budidaya tanaman anggrek.

b. Adapun produk fisik yang menjadi target luaran dalam kegiatan abdimas ini adalah:

1. Dihasilkannya mikroorganisme lokal (MOL) dari pemrosesan sampah organik.

2. Kualitas pertumbuhan tanaman anggrek yang dibudidayakan dengan baik.

\section{METODE DAN TEKNIK INTERVENSI}

Dalam upaya melaksanakan strategi pendekatan tersebut diatas, metode dan teknik intervensi yang dilakukan adalah sebagai berikut:

- Pendekatan personal

Pendekatan personal dilakukan kepada ibu-ibu peserta PKK, agar mau berpartisipasi dalam pembuatan MOL. Untuk itu, teknis yang dilakukan adalah melalui pembicaraan tatap muka, terutama bagi peserta yang kurang responsif pada kegiatan tersebut.

- Pendekatan kelompok

Agar pelaksanaan pembuatan MOL ini berjalan dengan efektif, pendekatan kelompok juga dilakukan sebagai upaya agar para peserta dapat saling berdiskusi satu sama lain sehingga dapat lebih memahami tata cara pembuatan MOL dan praktek pembuatannya.

\section{HASIL DAN PEMBAHASAN}

Kegiatan pembuatan MOL membutuhkan bahan, alat serta tahapan tertentu yang dapat menentukan keberhasilan dalam menghasilkan produk tersebut. Bahan-bahan yang diperlukan diantaranya adalah:

- $5 \mathrm{~kg}$ buah yang sudah busuk

- $1 / 2 \mathrm{~kg}$ gula merah dicairkan 
- $5 \mathrm{~kg}$ air kelapa

- 10 liter air tajin atau air cucian beras

- $\quad$ EM4 200cc

Selain bahan-bahan dasar yang diperlukan dalam pembuatan MOL, juga diperlukan alat-alat yang harus disediakan dalam membuat MOL, yaitu:

- Ember yang bertutup

- Pisau

- Talenan

- Saringan besar

- Sarung tangan plastik

- Lakban

- $\quad$ Gunting

Setelah bahan dan alat tersedia, maka perlu diketahui strategi pembuatan yang terdiri dari beberapa tahapan. Tahapan ini harus dilakukan secara berurutan, sehingga diperoleh hasil MOL yang baik. Tahapan tersebut adalah sebagai berikut:

- Cacah atau potong-potong halus dan remas buah yang sudah busuk.

- Masukkan irisan gula merah yang telah dicairkan ke dalam air tajin yang telah berada di dalam ember.

- Masukkan potongan buah ke dalam ember, dan tambahkan EM4 sebanyak $200 \mathrm{cc}$, lalu diaduk rata.

- Diamkan dalam keadaan tertutup untuk proses fermentasi selama 10-14 hari.

- $\quad$ Ember ditutup dan dilakban agar kedap udara (kondisi anaerob)

- Saring MOL buah, lalu larutkan 2 liter MOL buah ke dalam 20 liter air (perbandingan 1 : 10).

- Aduk rata dan semprotkan pada tanaman.

Adapun metode pembuatan MOL yang digunakan pada kegiatan abdimas ini adalah:

- Metode pelatihan secara teori.

- Metode pelatihan secara praktik atau demonstrasi.

- Metode aplikasi ke lapangan.

- Metode penyebaran kuesioner.

Metode yang pertama adalah pelatihan secara teori, yaitu pemberian materi secara teori tentang pembuatan MOL dan budidaya tanaman anggrek, khususnya tanamana angrek. Dalam pelatihan secara teori ini, tim abdimas menyebarkan leaflet yang telah dibuat beberapa hari sebelum kegiatan ini dimulai. Dalam leaflet menjelaskan bagaimana bahan, alat serta cara pembuatan MOL dari bahan limbah sayuran. Di samping cara pembuatan MOL, tim abdimas juga menjelaskan cara melakukan budidaya tanaman anggrek, yang meliputi pemilihan bibit, media tanam, penyiraman, kelembaban udara, sirkulasi udara, cahaya matahari, pemupukan, dan pemberantasan hama serta penyakit. 


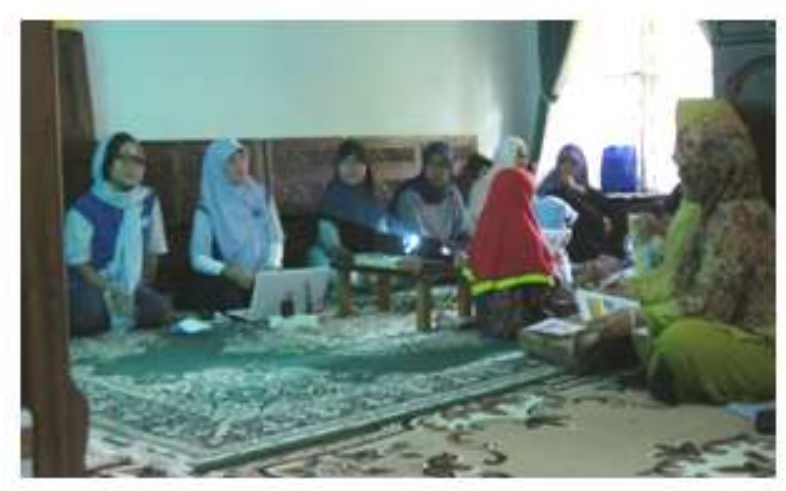

Gambar 2. Pelatihan pembuatan MOLsecara teori

Dalam pelatihan secara teori ini, peserta pelatihan mengikuti dengan antusias dan terjadi diskusi yang aktif antara tim abdimas dan peserta pelatihan. Pada umumnya peserta ingin mengetahui cara-cara pembuatan MOL yang berbahan dasar dari limbah sayuran. Selanjutnya mereka diberi tugas untuk mengumpukan limbah sayuran dan air tajin yang nantinya akan dibawa pada pelatihan secara praktik atau demonstrasi.

Metode yang kedua adalah pelatihan secara praktik atau demonstrasi. Kegiatan demonstrasi dilakukan setelah para anggota kelompok PKK diberikan pelatihan secara teori. Pada kesempatan ini tim abdimas memberi contoh pembuatan MOL secara praktik sesuai dengan tahapan-tahapannya. Sebelum kegiatan dimulai, tim abdimas memberikan bahan dan alat pembuatan MOL yaitu ember, gula merah, EM4, saringan, sarungtangan, lakban dan bunga anggrek. Para anggota kelompok PKK yang sudah membawa limbah sayuran dan air tajin segera dapat mempraktikan cara pembuatan MOL sesuai dengan contoh yang diberikan oleh tim abdimas. Selanjutnya MOL yang sudah ditempatkan dalam ember dan dilakban disimpan di rumah milik salah satu anggota kelompok PKK.



(1) Meremas buah-buah busuk

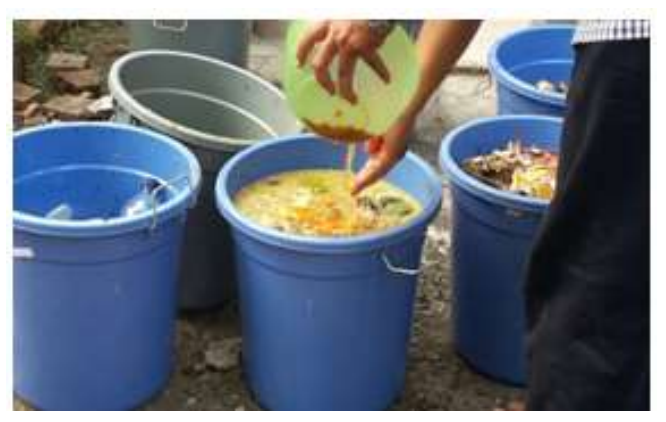

(3) Memasukkan irisan gula merah

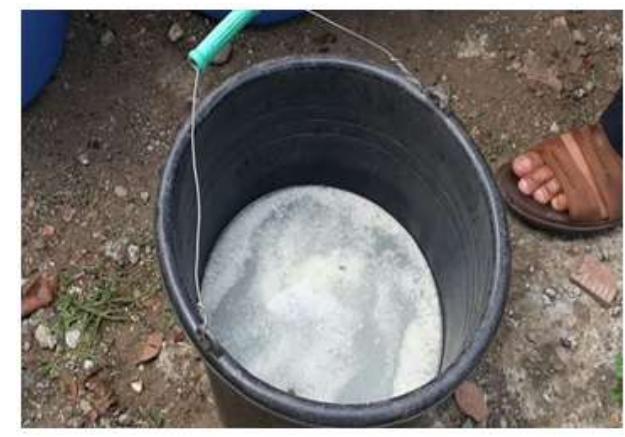

(2) Menyiapkan air tajin untuk dimasukkan kepotongan buah busuk

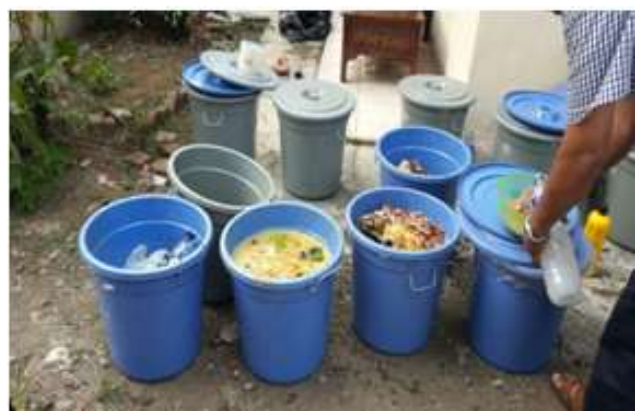

(4) Memasukkan air kelapa 


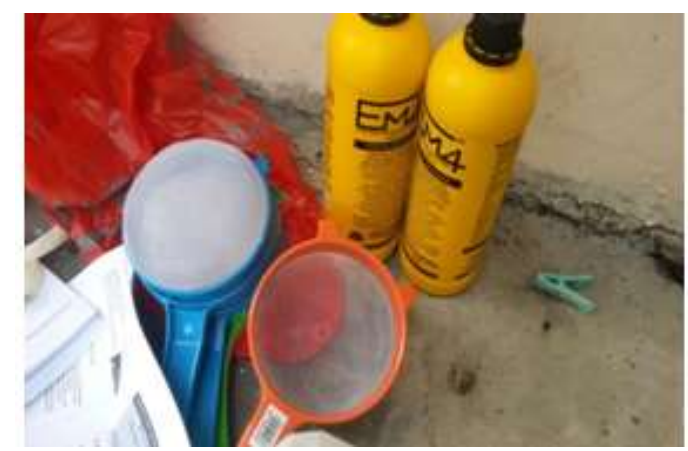

(5) Memasukkan EM4

Gambar 3. Pelatihan pembuatan MOL secara praktik

Metode yang ketiga adalah aplikasi MOL ke lapangan yaitu dengan cara menyemprotkan MOL pada tanaman anggrek jenis Dendrobium. Penyemprotan MOL diberikan sesuai dengan dosis, cara dan waktu yang tepat, yaitu dengan dosis pengenceran 1 liter MOL berbanding 10 liter air. Selanjutnya penyemprotan dilakukan dengan cara menyemprot seluruh bagian tanaman dengan MOL dari mulai daun, bunga, batang dan media tumbuh tanaman. Adapun waktu yang tepat pada pagi hari ataupun pada sore hari. Penyemprotan dilakukan 2 kali dalam seminggu.

Metode yang keempat adalah penyebaran kuesioner ke peserta pelatihan pembuatan MOL. Kuesioner ini bertujuan untuk menjaring tingkat pengetahuan, sikap mental, dan keterampilan peserta abdimas terhadap pembuatan mikroorganisme lokal (MOL) dan pemanfaatannya pada tanaman anggrek. Data yang diperoleh menunjukkan bahwa ditinjau dari segi pengetahuan, dapat dikatakan bahwa sebagian besar peserta, sudah mengetahui dan memahami tentang MOL dan pemanfaatannya. Secara rinci, peserta abdimas mengetahui tentang hal berikut:

- MOL adalah singkatan dari mikroorganisme lokal.

- MOL adalah cairan yang mengandung mikroorganisme hasil produksi sendiri dari bahan-bahan alami di sekitar kita.

- Bahan untuk membuat MOL diantaranya adalah gula merah, EM 4, air kelapa.

- Sampah organik dapat digunakan untuk membuat MOL.

- $\mathrm{MOL}$ dapat dimanfaatkan sebagai pupuk untuk tanaman anggrek.

Dari segi sikap mental, peserta juga memiliki sikap postif terhadap pembuatan MOL dan pemanfaatannya pada budidaya tanaman anggrek. Hal ini dapat diketahui dari sikap peserta terhadap beberapa hal berikut:

- Membuat MOL merupakan sesuatu yang perlu dicoba.

- Memberitahu orang lain tentang MOL dan manfaatnya merupakan hal penting.

- Memanfaatkan MOL sebagai pupuk tanaman anggrek perlu dilakukan.

- Mengetahui proses pembuatan MOL merupakan hal yang menarik.

- Sampah sayuran/buah yang digunakan untuk membuat MOL merupakan salah satu upaya untuk menjaga kebersihan lingkungan.

Hal yang sama juga untuk keterampilan, dimana pada umumnya peserta sudah mengetahui tahapan-tahapan dalam membuat MOL, bahkan sebagian ada yang sudah bisa mempraktekkan tahapan-tahapan tersebut. Tahapan pembuatan MOL tersebut adalah sebagai berikut:

- Ada beberapa tahapan dalam membuat MOL.

- Tahapan pertama adalah mencacah atau potong-potong halus dan meremas buah yang sudah busuk. 
- Memasukkan irisan gula merah yang telah dicairkan ke dalam air tajin yang telah berada di dalam ember adalah tahapan kedua.

- Memasukkan potongan buah ke dalam ember, dan menambahkan EM4 sebanyak 200 cc, lalu diaduk rata, merupakan tahap ketiga.

- Tahap terakhir, didiamkan dalam keadaan tertutup untuk proses fermentasi selama 10-14 hari.

Namun ada beberapa masukan yang diberikan peserta yaitu bahwa ada perbedaan antara tahapan yang disebutkan dalam teori dengan tahapan yang diberikan saat demontrasi. Namun, hal ini sebenarnya tidak masalah karena perbedaan yang dimaksud bukanlah merupakan hal yang prinsip.

\section{ANALISIS KEBUTUHAN}

Pada dasarnya pertimbangan melakukan kegiatan abdimas di kelompok PKK Taman Darmaga Bogor sangat mempertimbangkan kebutuhan sasaran. Proses perubahan perilaku sasaran berkaitan erat dengan kebutuhan sasaran itu sendiri. Perilaku yang dimaksud adalah pengetahuan, sikap dan keterampilan. Proses perubahan akan efektif menghasilkan perubahan apabila cara pendekatannya disesuaikan dengan kebutuhan sasaran.

Pengertian kebutuhan adalah sesuatu yang ingin atau harus diperoleh dalam mengisi kehidupannya. Kebutuhan tersebut akan berbeda bagi tiap orang tergantung dari harapan-harapannya, serta kondisi yang sedang dihadapi oleh masing-masing orang tersebut. Kebutuhan seseorang akan sesuatu dapat mengakibatkan perilaku tertentu dari orang tersebut. Jenis-jenis kebutuhan manusia diantaranya adalah kebutuhan primer, kebutuhan sekunder, dan kebutuhan tersier.

Kebutuhan primer yaitu kebutuhan yang menyangkut sandang, pangan, dan rumah. Kebutuhan sekunder merupakan kebutuhan penunjang dalam mempertahankan atau meningkatkan taraf hidup seseorang, misalnya kebutuhan akan pendidikan dan kesehatan. Kebutuhan tersier merupakan kebutuhan yang tidak terlalu esensial yang sifatnya memberikan kenyamanan lebih bagi seseorang. Kebutuhan ini dapat berupa kebutuhan akan hiburan atau pemilikan barang-barang mewah.

Terkait dengan abdimas ini, yang merupakan kebutuhan sasaran adalah kebersihan lingkungan, terutama kebersihan sekitar rumah dari sampah-sampah khususnya sampah rumahtangga. Dengan kata lain bagaimana membuat berarti sampah rumahtangga atau bagaimana mendaurulang sampah rumahtangga menjadi produk yang berarti bagi lingkungan.

\section{INTERVENSI}

Intervensi yang dilakukan dalam rangka peningkatan kualitas hidup, khususnya bidang kesehatan dalam mendaurulang sampah rumahtangga salah satunya adalah dengan pembuatan MOL. Pembuatan MOL di samping sebagai upaya dalam pemanfaatan limbah rumahtangga khususnya sayuran untuk diaplikasikan ke tanaman anggrek, juga menjadi ajang tim abdimas dalam rangka melaksanakan kegiatan Tri Darma Perguruan Tinggi.

\section{KESIMPULAN DAN REKOMENDASI}

Dari paparan yang diberikan, dapat disimpulkan bahwa kegiatan abdimas yang diberikan kepada ibu-ibu PKK Taman Dramaga Permai di Bogor, sudah sesuai dengan tujuan dan target luaran yang diharapkan, yaitu agar peserta tahu (pengetahuan), mau (sikap mental), dan mampu (keterampilan) melaksanakan pembuatan MOL dan pemanfaatanya pada budidaya tanaman anggrek. Selanjutnya, diharapkan ibu-ibu peserta abdimas dapat mempraktekkan pembuatan MOL ini secara kontinyu dan berkelanjutan.

\section{REKOMENDASI}

Perlu dilakukan pembuatan MOL untuk yang berbahan dasar selain limbah sayuran, sehingga responden mempunyai lebih dari satu pilihan sesuai dengan bahan dasar yang tersedia di lapangan. 


\section{REFERENSI}

Anonim. (2002). Bungakan Dendrobium Skala Komersial. Depok: Redaksi Trubus.

Anonim. (2005). Anggrek Bunga dengan Aneka Pesona Bentuk dan Warna. Jakarta: Redaksi Agromedia, Jakarta, 2005.

Anonim. (2011). Pemanfaatan MOL. https://p2aph.wordpress.com/2011/03/24/pemanfaatan-molmikroorganisme-lokal/. Diakses tanggal 25 Maret 2015.

Endah, J. (2008). Membuat Tanaman Anggrek Rajin Berbunga. Jakarta: PT. Agromedia Pustaka.

Mulyono. (2014). Membuat Mol dan Komposdari Sampah RumahTangga. Jakarta: PT. Agromedia Pustaka.

Sandra, E. (2006). Membuat Anggrek Rajin Berbunga. Jakarta: Agromedia Pustaka.

Sholah, AA. (2010). Cara Membuat MOL-Mikroorganisme Lokal. http://pusatpromosiindonesia. blogspot.co.id/2014/08/cara-membuat-mol-mikro-organisme-lokal.html. Diakses tanggal 20 Oktober 2015.

Soeleman, S \& Donor Rahayu. (2014). Halaman Organik. Jakarta: Agromedia Pustaka.

Syafrezani, S.N. (2009). Manfaat Tumbuhan Bunga Penghias Pekarangan. Bandung: Titian IImu. 